\title{
Dietary supplementation with camu-camu and continuous exercises in the treatment of obesity
}

\section{Suplementação dietética com}

camu-camu e exercícios contínuos no

tratamento da obesidade

\author{
Ozanildo Vilaça do NASCIMENTO1 (iD) 0000-0002-5030-8084 \\ Ana Paula de Araújo BOLETI2 (ID) 0000-0002-0253-8907 \\ Maíra SCHWERTZ ${ }^{3}$ (iD) 0000-0002-0514-3217 \\ Emerson Silva LIMA² (D) 0000-0002-9367-2812
}

\section{A B S T R A C T}

\section{Objective}

The goal of this study were to investigate the effects of continuous exercise with/or without the ingestion the Camu-camu pulp in a rat model of obesity.

\section{Methods}

Neonate male Wistar rats, receiving monosodium glutamate, subcutaneously were separated into foour groups: sedentary group $\mathrm{S}$ (no treatment), exercise group $\mathrm{E}$ (continuous swimming training), Camu-camu group C (25mL of pulp of Camu-camu/day) and exercise and Camu-camu group EC ( $25 \mathrm{~mL}$ of pulp of Camu-camu/day, continuous swimming). After 12 weeks, the animals were received euthanasia.

1 Universidade Federal do Amazonas, Faculdade de Educação Física, Departamento de Fundamentação Teórica. Manaus, AM, Brasil.

2 Universidade Federal do Amazonas, Faculdade de Ciências Farmacêuticas. R. Alexandre Amorim, 330, Aparecida, 69080-005, Manaus, AM, Brasil. Correspondência para/Correspondence to: ES LIMA. E-mail: <eslima@ufam.edu.br>.

3 Instituto Nacional de Pesquisa da Amazônia, Coordenação de Pesquisas em Ciências da Saúde. Manaus, AM, Brasil.

Como citar este artigo/How to cite this article

Nascimento OV, Boleti APA, Schwertz M, Lima ES. Dietary supplementation with camu-camu and continuous exercises in the treatment of obesity. Rev Nutr. 2018;31(1):25-33. https://doi.org/10.1590/1678-98652018000100003 


\section{Results}

The exercise program was conducted for five days for 12 weeks and the effects of supplementation with or without Camu-camu in obese rats were analyzed, showing that the relative levels of the variables cholesterol, triglycerides, glucose, High Density Lipoprotein and Low Density Lipoprotein and in all groups there was a significant reduction $(p<0.001)$, except for the control group. Body weight and feed intake, epididymal and visceral fat deposits were not significantly different between the means of groups $C$ and $E$, but these groups showed a significant difference when compared to the EC group $(p<0.001)$.

\section{Conclusion}

The results demonstrate the effectiveness of continuous exercise and diet supplemented with Camu-camu fruit pulp to control obesity.

Keywords: Body weight. Diet, reducing. Obesity.

\section{R E S U M O}

\section{Objetivo}

O objetivo deste estudo foi investigar os efeitos do exercício contínuo, com ou sem a ingestão da polpa de camu-camu, em um modelo de ratos obesos.

\section{Métodos}

Ratos machos neonatos Wistar receberam glutamato monossódico subcutaneamente e foram separados em três grupos: grupo de exercício E (treinamento de natação contínuo); grupo exercitado e suplementado com camu-camu - EC (natação contínua e administração de camu-camu); e grupo sedentário S (sem tratamento), como controle. Concluído o experimento, os animais sofreram eutanásia.

\section{Resultados}

O experimento teve a duração de doze semanas. O protocolo de exercício de natação (120min) e a ingestão da suplementação com camu-camu de polpa $(25 \mathrm{~mL})$ tiveram a mesma duração e foram feitas simultaneamente cinco vezes por semana. Os resultados apontaram redução significativa $(p<0,001)$ dos níveis relativos das variáveis colesterol, triglicérides, glicose, High Density Lipoprotein e Low Density Lipoprotein nos dois primeiros grupos, quando comparados ao grupo controle. Quanto a peso corporal e consumo de ração, depósitos de gordura epididimal e visceral, não houve diferença significativa entre as médias dos grupos C e $E$ - porém, estes grupos apresentaram diferença significativa quando comparados ao grupo suplementado com camu-camu $(p<0,001)$.

\section{Conclusão}

Os resultados demonstraram a efetividade do exercício contínuo e da dieta suplementada com a polpa de camu-camu para o controle da obesidade.

Palavras-chave: Peso corporal. Dieta redutora. Obesidade.

\section{NTRODUCTION}

The growth in the number of people with diseases associated to the weight excess make the experts consider obesity a disease with serious problems to public health [1]. The excess of adipose tissue with abdominal distribution, has been associated to the growth of incidence of several kinds of diseases especially the ones related to the metabolic syndrome [2].

Considering obesity is multifactorial, one of the strategies to be used would be the adoption of a heathy and balanced diet supplying the daily energy intake and make the individual adept regular physical activities $[3,4]$. Some studies show the use of physical activities as a cooperator in the treatment not only when the individual is exercising, but a series of adjetments after the activity, avoiding the unwanted body fat gains [4-6].

The Camu-camu (Myrciaria dubia H.B.K. McVaugh) is in the riversides of the Black River in Amazon and contains a remarkable content of ascorbic acid containing from 1,600 to 6,112 
$\mathrm{mg} / 100 \mathrm{~g}$ of pulp [7] what makes it one of the richest in vitamin $C$ if compared to other citric fruit and, in it nutritional composition, various antioxidanting components [8-10]. Some studies confirm the use of Camu-camu with antimicrobial [11] effects, antiglycemic [12], antihypertensive [13], anticancer and avoids oxidative damages in hepatic and brain cells [14] contributing for quality life improvement [15].

In the present study, we demonstrated that the pulp of Camu-camu reduced body weight and epididymal and visceral fat, such as reduced fat deposited in the face, heart and liver, in addition to decrease the inflammatory proteins [16]. Several experimental studies have shown that exercise combined with continued dieting results in reduced adiposity, lipid profile and reduction of biochemical parameters in rats [17-19].

The aim of this study is to identify the potential effect of exercise combined with the pulp of Amazon fruit Camu-camu in reducing health risk factors associated with obesity and lipid profile.

\section{METHODS}

This experiment was performed using 3-month-old $(360.84 \pm 45.44 \mathrm{~g})$ male Wistar rats (Rattus norvegicus var. albinus) ( $n=32)$. The animals were obtained from the Instituto Nacional de Pesquisas da Amazônia (INPA, Amazon Research Institute). The procedures adopted with animals were performed in accordance with the criteria of the law $n^{0} 11.794$ of 2008 for use of animals for scientific purposes. Each animal was housed in an individual cage, with a temperature of $26 \pm 2^{\circ} \mathrm{C}$, and with a light-dark cycle of 12 hours. They received water and commercial rations ad libitum (Labina, São Paulo, Brazil). The animals were divided into four groups $(n=8)$ according to the execution of the exercise (E-swimming 120 min/5 times per week) exercise and diet supplemented (EC-swimming 120 min/5 times per week and a diet supplemented with $25 \mathrm{~mL}$ of Camu-camu) (C-supplemented with $25 \mathrm{~mL}$ of (amu-camu) and sedentary group (S). The animals were evaluated after 12 weeks of 12 weeks of intervention The methodology was approved by the Bioethics Committee in Animal Experimentation of the Universidade Federal do Amazonas ( $n^{\circ} 23105.003147 / 2010$ ).

Twenty-four hours after birth, the offspring of the Wistar rats (Rattus norvegicus var. Albinus) were injected subcutaneously in the neck with monosodium glutamate (Ajinomoto ${ }^{\circledR}$, São Paulo, Brazil) at a daily dosage of $4 \mathrm{mg} / \mathrm{g}$ body weight in a volume of $0.2 \mathrm{~mL}$, until they were 14 days old [20]. At 22 days old, the offspring were weaned. Adults animals were followed from the 3rd up the 6th month of life.

The fruit was obtained from Yurican Farm, 100km from highway AM 010 in the municipality of Rio Preto da Eva, Amazonas, Brazil. The fruits were selected, washed with chlorinated water (1.0\% sodium hypochlorite). The bleaching was done in boiling water at $70^{\circ} \mathrm{C}$ : a stainless steel basket containing approximately $3 \mathrm{~kg}$ of fruits was immersed for two minutes in water heated by gas burners. The cooling of blanched fruits was performed immediately after bleaching, by immersing the basket containing the Camu-camu in an ice bath until it reached a temperature close to the environment, soon after the pulping was carried out to obtain the pulp [7].

The experimental groups received the following diets ad libitum (in pads) of Labina (São Paulo, Brazil) and contained $23 \mathrm{~g}$ of protein (per $100 \mathrm{~g}$ diet), $49 \mathrm{~g}$ carbohydrate, $4 \mathrm{~g}$ total fat, $5 \mathrm{~g}$ fiber, $7 \mathrm{~g}$ of ash, and $6 \mathrm{~g}$ of vitamins (E and $\mathrm{S}$ ); the diet groups ( $E C$ and $C$ ) received macerated feed and mixed with $25 \mathrm{~mL}$ of Camu-camu pulp, daily for twelve weeks. The exercise program consisted of swimming in individual tanks filled with water and maintained at $28-32^{\circ} \mathrm{C}$. Animals in groups (E and EC) swam for 30,60 and 90min of the first, second and third days to adapt. The 
swimming period was subsequently increased to $120 \mathrm{~min} /$ day. A weight of $5 \%$ of body weight was attached to the tail of each swimming rat. The exercise was conducted for five days a week for 12 weeks. Body weight, food intake, water, feces and body weight were recorded weekly.

At the end of the experiment, rats were weighed and anesthetized by overdose of choral hydrate i.p. The groups received euthanasia in the same period. Blood samples $(5 \mathrm{~mL})$ were withdrawn and stored in tubes and centrifuged at 3.000rpm for 5 minutes for further biochemical determinations. Immediately after sacrifice, an incision was made in the abdomen, and the following tissues were removed and weighed using a scalpel and forceps: white adipose Epididymal (EPI), Visceral (VIS). Levels of cholesterol, glucose, and triglyceride fractions were measured by enzymatic colorimetric method using commercial kits (Labtest Diagnóstica, MG, Brazil) by automation (Cobas mira Plus ${ }^{\circledR}$, Roche). After precipitation of Low Density Lipoprotein $(\mathrm{LDL})$ and Very Low Density Lipoprotein (VLDL) by phosphotungstic acid/MgCl2, High Density Lipoprotein-cholesterol (HDL-c) in the supernatant was determined using a commercial kit (Labtest Diagnóstica, MG, Brazil). Low Density Lipoprotein-cholesterol (LDL-c) was calculated using a Friedewald formula.

Results are expressed as mean \pm standard deviation. Comparisons between initial and final measures were statistically verified using paired t-tests. One-way Analysis of Variance (ANOVA) was used to compare data between groups. The multiple comparisons between groups as for the result of final to initial difference were done using Tukey test. The software used was Minitab 18.

\section{RE S U L T S}

The exercise program was conducted for five days for 12 weeks and the effects of the supplementation with/or without Camu-camu pulp in obese rats were analyzed, as shown in the Table 1. The relative levels of the variables cholesterol, triglycerides, glucose, HDL and $L D L$ and $p$-value for the test of the difference between the final and initial means in all groups showed a significant reduction of cholesterol $(p<0.001)$, except for the control group. Comparing the groups, the highest cholesterol reduction occurred in group E (Figure 1). For the triglyceride and glucose variables, there was also a significant reduction in all groups, and the group supplemented and exercised presented the highest glucose reduction while the Camucamu group had the highest triglyceride indices, these variables were increased in the control group (Table 1). HDL showed a significant increase in all groups except the control group (Table 1). However, the group treated with Camu-camu had the highest HDL increase. There was no significant difference in LDL levels between groups except in the control group, but group $E$ had the lowest reduction $(p<0.001)$. The variables triglycerides, glucose, visceral fat, body weight and feed intake did not present significant differences between the means of groups C, E and $E C$, but presented a significant difference for group S (Table 2). For the cholesterol variable, we observed a significant mean difference of groups E, C and EC for group S, as well as group C for group EC (Table 2). There was no significant difference between groups $C$ and $E$ and between groups $C$ and EC in the triglyceride variable. For epididymal fat deposits there was no significant difference between the means of groups $C$ and $E$, but these groups showed a significant difference when compared with the EC group, the same responses were measured for epididymal fat.

\section{DISCUSSION}

Schoolars consider obesity as an incrising epidemic in several worldwide societies, the unbalanced feeding and the lack of physical activity practise are factors that contribute for it. 

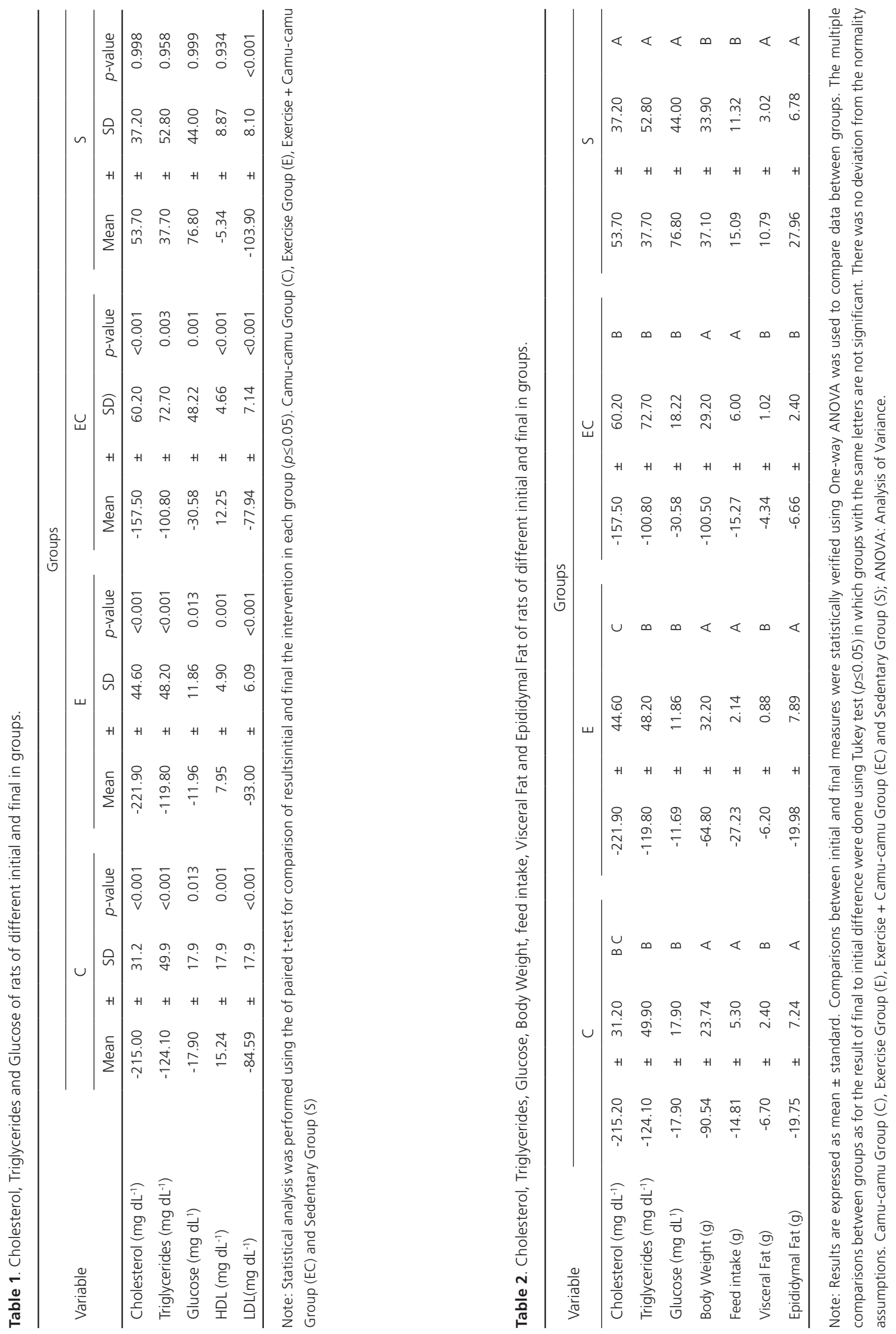
A

Cl 95\% for average by group

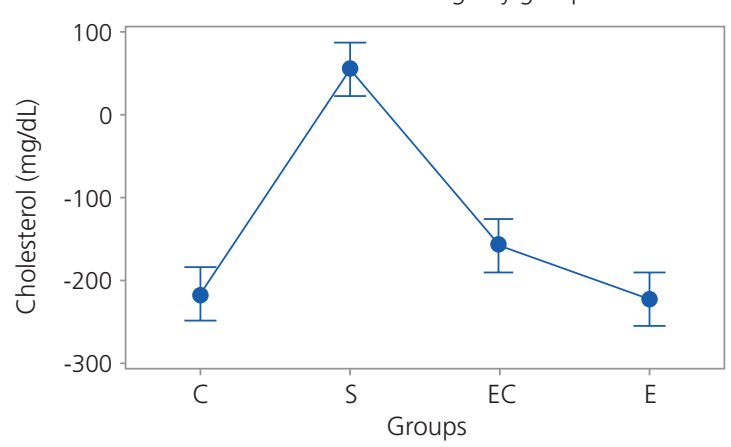

C

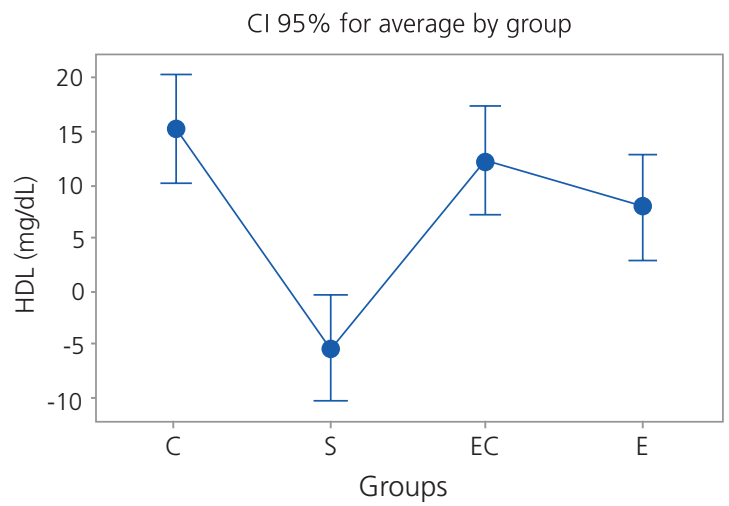

B



D

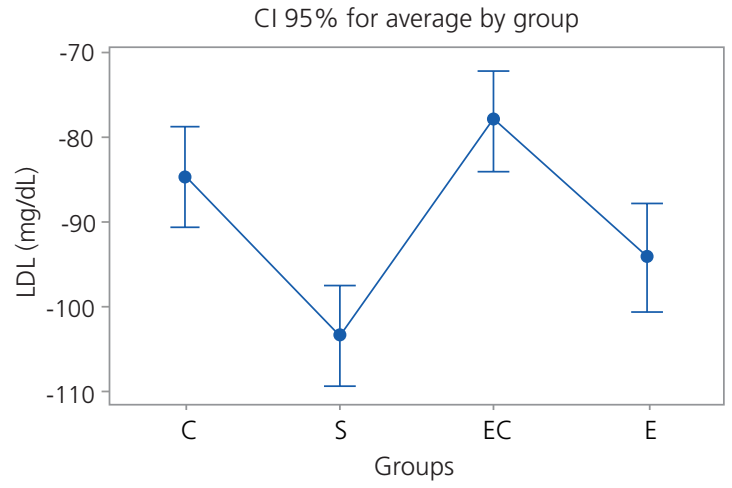

Figure 1. IC $95 \%$ for average by groups. (A) Cholesterol ( $\left.\mathrm{mg} \mathrm{dL}^{-1}\right)$, (B) Triglycerides ( $\left.\mathrm{mg} \mathrm{dL}^{-1}\right)$, (C) HDL (mg dL-1) and (D) LDL $\left(m g \mathrm{dL}^{-1}\right)$. Note: HDL: High Density Lipoprotein; LDL: Low Density Lipoprotein; Cl: Confidence Interval.

Therefore, researches envolving physical activities and balanced diets are indispensable either on humans or experimental models [21-24]. Beside that, the caloric expenditure occasioned during and after the physical activity helps to reduce the adverse effects of the body fat gather specially the one placed in the abdominal wall, adding the balanced energy intake can be prescribed as a proposal to prevent obesity. Yet there is no agreement in literature about intensity, frequency and duration of the physical activity and what kind of diet promote different adaptations and effects when it comes to obesity $[25,26]$.

This study showed that the group (EC) presented the largest final body weight reduction followed by groups C and E (Table 2). Physical exercise acts positively in the prevention and development of obesity, because it causes a series of physiological responses, resulting among other adaptations of lipid metabolism enzymes and the use of fats as energy source and, when associated with changes in diet, influence positively in almost all factors and risk of obesity. Demonstrating that both fruit and physical exercise protects against gains in body weight and adiposity. In addition, when the values of the visceral and epididymal fat deposits were added, both groups of rats that received the intervention in isolation, exercise or Camu-camu even without significant body weight reduction when compared with the group (EC) had values reduced in these deposits (Table 2 ). The exercise protocol was shown to act directly not only on body weight reduction, but on deposits 
of different fatty tissues such as visceral and epididymal, raising the hypothesis that these tissues may also contribute to the energy expenditure requested by the exercise. Findings found in this research corroborate similar results of swimming protocols used by other authors [26-29].

Demonstrating that both fruit and physical exercise protects against gains in body weight and adiposity. In addition, when the values of the visceral and epididymal fat deposits were added, both groups of rats that received the intervention in isolation, exercise or Camu-camu even without significant body weight reduction when compared with the group (EC) had values reduced in these deposits (Table 2 ). The light intensity of swimming exercises to moderate and stimulate the consumption of oxygen, stimulates the action of the lipase enzyme hormone sensitive providing preferably fatty acids, as a result of lowering the levels of adiposity [30] Regarding the diet of the literature reports that the fruit of Camu-camu has anti-oxidative and anti-inflammatory properties which may have contributed to the reduction of fat deposits $[31,32]$ since there was a decrease in body weight and its fat deposits reported in this study. Lipid profile markers were another marker of obesity risk investigated in our experiment. The isolated group that used Camu-camu showed the best results in the triglyceride and HDL levels, while the exercise group lowered cholesterol and LDL levels, results not found in the group that associated Camu-camu with exercise (Table 1). Researchers report results of biological assays on the action of Camu-camu (Myrciaria dubia H.B.K. McVaugh) on the reduction of lipid profile and lipid peroxidation, on triglyceride levels with decreased hypercholesterolemia in obese and diabetic rats $[16,33,34]$ cholesterol reduction total cholesterol, $\mathrm{LDL}-\mathrm{C}$, triglycerides and modifications in the metabolic profile of adults with metabolic syndrome $[35,36]$.

It has already been discussed in this text the importance of aerobic swimming exercise in the mobilization of fatty tissues, which may imply alterations in lipid metabolism and lipoprotein levels specifically, with increased enzyme activity, favoring a higher catabolism of lipoproteins rich in triglycerides, forming less atherogenic LDL particles $[35,36]$ which leads to the hypothesis that the fruit has a potential of bioactive compounds in its nutritional composition with several antioxidant components [7-9,37] which may have potentiated the reduction of lipid markers. The control of the availability of energy substrates in the exercise is determined largely by hormonal adjustments, mainly the decrease of insulin, contributing to increase the effect of counter regulatory hormones on the liver, favoring the production of glucose, increasing the mobilization of adipose tissue triglycerides and muscular and muscular glycogen [4].

Although visceral obesity plays a significant role in the development and maintenance of insulin resistance, in this research there was a significant reduction in the body weight of the rats in the supplemented and exercised group (Table 2) which may have contributed to glucose utilization by exercise. In addition to the participation of exercise in the control of glucose metabolism, the Camu-camu pulp can be indicated for this same purpose as already found in biological assays in adults [33-36].

\section{CONCLUSION}

In an experimental model using monosodium glutamate, the association of Camu-camu with physical exercise was effective in reducing body weight. In addition, the values of the visceral and epididymal fat deposits, both groups of rats that received the isolated intervention of the exercise or Camu-camu had reduced values in these deposits. In the lipid profile markers the group supplemented with Camu-camu showed the best result in triglyceride and HDL levels, while the exercised group lowered cholesterol and LDL levels. In addition the group exercised 
and Camu-camu was the one that best utilized the glucose levels. The results found in this experimental study are promising. However, further studies are needed to clarify the mechanisms of action found in these.

\section{A CKNOWLEDGMENTS}

The authors recognize support provided by Fundação de Amparo à Pesquisa do Estado do Amazonas (FAPEAM, Foundation for the Support of Research in the State of Amazonas) and Conselho Nacional de Desenvolvimento Científico e Tecnológico (CNPq, National Council for Scientific and Technological Development). Ana Paula de Araujo Boletti is a researcher from the Programa de Desenvolvimento Científico Regional. AcademicEnglishSolutions.com revised the English. We would like to thank Lucia Kiyoko Ozaki Yuyama in memorian for the fundamental participation in this work.

\section{RE FERE N CE S}

1. Olafsdottir AS, Torfadottir JE, Arngrimsson SA. Health behavior and metabolic risk factors associated with normal weight obesity in adolescents. PloS One. 2016;11(8):e0161451.

2. Oliveira CCD, Costa EDD, Roriz AKC, Ramos LB, Gomes Neto M. Predictors of Metabolic Syndrome in the Elderly: A Review. Int J Cardiovasc Sci. 2017;30(4):343-53.

3. Wang $T$, Huang $T$, Kang JH, Zheng $Y$, Jensen, MK, Wiggs $\mathrm{JL}$, et al. Habitual coffee consumption and genetic predisposition to obesity: Gene-diet interaction analyses in three US prospective studies. BMC Med. 2017;15(1):97.

4. Hames KC, Coen PM, King WC, Anthony SJ, Stefanovic-Racic M, Toledo FG, et al. Resting and exercise energy metabolism in weight-reduced adults with severe obesity. Obesity. 2016;24(6):1290-8.

5. Monnerat Marino Rosa F, Fernandes Filho J, Vidal Linhares R, Vale Quaresma JC, Carneiro I, Regis $J$, et al. Effects of acute exercise with upper body cycle ergometer in individuals with morbid obesity. Rev de Salud Publica (Bogota). 2016;18(1):37-49.

6. Keating $S E$, Hackett DA, Parker HM, Way KL, O'Connor HT, Sainsbury A, et al. Effect of resistance training on liver fat and visceral adiposity in adults with obesity: A randomized controlled trial. Hepatol Res. 2017;47(7):622-31.
7. Yuyama K, Aguiar JPL, Yuyama LKO. Camu-camu: um fruto fantástico como fonte de vitamina $C$. Acta Amaz. 2002;32:169-74.

8. Grigio ML, Chagas EA, Rathinasabapathi B, Chagas PC, Silva ARV, Sobral STM, et al. Qualitative evaluation and biocompounds present in different parts of camu-camu (Myrciaria dubia) fruit. Afr J Food Sci. 2017;11(5):124-9.

9. Zanatta $C F$, Cuevas E, Bobbio FO, Winterhalter $P$, Mercadante AZ. Determination of Anthocyanins from Camu-camu (Myrciariadubia) by HPLC PDA, HPLC- MS, and NMR. J Agric Food Chem. 2005;53(24):9531-5.

10. Flores JF, Edwin MR. Factores que influyen en la rentabilidad económica de la producción del cultivo de camu camu en la selva peruana. Tzhoecoen. 2017;9(1):94-106.

11. Mori T, Ruiz E, García M, Bardales J, TresierraAyala Á, Bendayán M, et al. Efecto antimicrobiano de Myrciaria dubia (camu-camu) y Cyperus luzulae (piri piri) sobre microorganismos patógenos. Conoc Amaz. 2016;4(1):49-57.

12. Fujita A, Sarkar D, Genovese MI, Shetty K. Improving anti-hyperglycemic and anti-hypertensive bioactive properties of camu-camu (Myriciaria dubia Mc. Vaugh) using lactic acid bacterial fermentation. Process Biochem. 2017;32:1-32. https://doi.org/10. 1016/j.procbio.2017.05.017

13. Aguirre A, Nattier S, Benites Carranza CY. Efecto del fruto de Myrciaria dubia (hbk) mcvaugh sobre cáncer colorrectal inducido en rattus norvegicus var. albinus [tesis]. Trujillo: Universidad Nacional de Trujillo; 2017 [acceso 2017 mar 22]. Disponible en: http://dsapce.unitru.edu.pe/handle/UNITRU/7437

14. Özkan F, Gündüz SG, Berköz M, Arzu Ö, Hunt SY. The protective role of ascorbic acid (vitamin C) against chlorpyrifos-induced oxidative stress in Oreochromis niloticus. Fish Physiol Biochem. 2012;38(3):635-43.

15. Arellano-Acuña E, Rojas-Zavaleta I, Paucar-Menacho LM. Camu-camu (Myrciaria dubia): Fruta tropical de excelentes propiedades funcionales que ayudan a mejorar la calidad de vida. Sci Agropecu. 2016;7(4):433-43.

16. Nascimento OV, Boleti APA, Yuyama LKO, Lima ES. Effects of diet supplementation with Camucamu (Myrciaria dubia HBK McVaugh) fruit in a rat model of diet-induced obesity. An Acad Bras Ciênc. 2013;85(1):355-63.

17. Ammar NM, Farag MA, Kholeif TE, Metwally NS, EL-Sheikh NM, EL Gendy AN, et al. Serum metabolomics reveals the mechanistic role of functional foods and exercise for obesity 
management in rats. J Pharm Biomed Anal. 2017;142:91-101.

18. Shen Y, Huang G, McCormick BP, Song $T, X u X$. Effects of high-intensity interval versus mildintensity endurance training on metabolic phenotype and corticosterone response in rats fed a high-fat or control diet. PloS One. 2017;12(7):e0181684.

19. Medeiros RF, Gaique TG, Bento-Bernardes T, Kindlovits R, Gomes TM, Motta NAV, et al. Arginine and aerobic training prevent endothelial and metabolic alterations in rats at high risk for the development of the metabolic syndrome. $\mathrm{Br} J$ Nutr. 2017;118(1):1-10.

20. Costa-Pereira LV, Melo DS, Santos CS, Mendes BF, Esteves EA, Lacerda ACR, et al. Distinct beneficial effects of continuous vs accumulated exercise training on cardiovascular risk factors in Wistar rats. Scand J Med Sci Sports. 2016;8(26):859-988.

21. Scott D, Harrison CL, Hutchison S, De Courten B, Stepto NK. Exploring factors related to changes in body composition, insulin sensitivity and aerobic capacity in response to a 12-week exercise intervention in overweight and obese women with and without polycystic ovary syndrome. Plos One. 2017;12(8):e182412.

22. Rezende R, Santos C, Dubow C, Vargas SC, Pohl $\mathrm{HH}$, Paiva DN. Effects of physical exercise on insulin resistance to obese individuals. Cinergis. 2016;17(3):1-5.

23. Wnuk S, Chau DU. Mindful Eating for Severe Obesity. In: Psychiatric Care in Severe Obesity. New York: Springer International Publishing; 2017. p.231-44.

24. Gamelin FX, Aucouturier J, lannotti FA, Piscitelli F, Mazzarella E, Aveta T, et al. Effects of chronic exercise on the endocannabinoid system in Wistar rats with high-fat diet-induced obesity. J Physiol Biochem. 2016;72(2):183-99.

25. Giles ED, Jackman MR, MacLean PS. Modeling diet-induced obesity with obesity-prone rats: Implications for studies in females. Front Nutr. 2016;3:1-13. https://doi.org/10.3389/fnut.2016.0 0050

26. Dhasarathy A, Roemmich JN, Claycombe KJ. Influence of maternal obesity, diet and exercise on epigenetic regulation of adipocytes. Mol Aspects Med. 2017;54:37-49.

27. Rocha GLD, Crisp AH, De Oliveira MR, Silva CAD, Silva JO, Duarte AC, et al. Effect of high intensity interval and continuous swimming training on body mass adiposity level and serum parameters in high-fat diet fed rats. Sci Worl J. 2016;2016:1-8.
28. Motta VF, Aguila MB, Mandarim-de-Lacerda CA. Efectos beneficiosos del entrenamiento con intervalos de alta intensidad en la obesidad inducida por dieta en ratones: tejido adiposo, estructura del hígado e islotes pancreáticos. Int J Morphol. 2016;34(2):684-91.

29. Castoldi RC, Coladello LF, Koike TE, Ozaki GAT, Magalhães AJB, Papoti $M$, et al. Effect of body composition on aerobic capacity of animals submitted to swimming exercise. Rev Bras Cineantropom Desempenho Hum. 2016;18(2):136-42.

30. Rocha-Rodrigues $S$, Rodríguez A, Becerril $S$, Ramírez B, Gonçalves IO, Beleza J, et al. Physical exercise remodels visceral adipose tissue and mitochondrial lipid metabolism in rats fed a high-fat diet. Clin Exp Pharmacol Physiol. 2017;44(3):386-94.

31. Inoue T, Komoda H, Uchida T, Node K. Tropical fruit camu-camu (Myrciaria dubia) has. J Cardiol. 2008;52(2):127-32.

32. Asif M. Bioactive phytochemical constituents of some edible fruits of myrtaceae family. Am J Nut Res. 2015;1(1):1-17.

33. Espada M, Reis J, Alves F. Relação entre cinética do consumo de oxigénio em diferentes domínios de intensidade de exercício e o desempenho na natação. Rev UIIPS. 2014;2(2):236-53

34. Gonçalves AESS, Lellis-Santos C, Curi R, Lajolo FM, Genovese MI. Frozen pulp extracts of camucamu (Myrciaria dubia McVaugh) attenuate the hyperlipidemia and lipid peroxidation of Type 1 diabetic rats. Food Res Int. 2014;64:1-8.

35. Murta GC. Desenvolvimento e efeito de bebida tipo shake à base de pó de camu-camu (Myrciaria Dubia [H.B.K.] McVaugh) no controle da diabetes, in vivo [dissertação]. Manaus: Instituto Nacional de Pesquisas da Amazônia; 2017.

36. Oliveira AS. Impacto do consumo de camu-camu (Myrciaria Dubia (Kunth) Mc Vaugh) em adultos com síndrome metabólica em Boa Vista/RR [dissertação]. Manaus: Universidade Federal do Amazonas; 2015.

37. Vargas BL, Gonçalves FA, Yuyama LKO, Do Amaral Souza FDC, Aguiar JPL. Efeito das cápsulas de camu-camu sobre a glicemia e o perfil lipídico de adultos saudáveis. Rev Cuba Plantas Med. 2015 [acesso 2017 abr 14];20(1):48-61. Disponível em: http://revplantasmedicinales.sld.cu/index.php/pla/ article/view/136 